\title{
The Difference Of Effectiveness Way To Consume Iron Tablets Toward Haemoglobin Level Changes to Pregnant Women In Second Trimester at The Sindang Barang Community Health Center In 2017
}

\author{
Triswanti, Tri Maghfiroh \\ Akademi Kebidanan Wijaya Husada Bogor, Indonesia \\ Corresponding author : wijayahusada@gmail.com
}

\begin{abstract}
Background: Giving iron tablets together with drinking orange juice can increase hemoglobin levels higher than administering iron tablets alone

Purpose: This study aims to examine the differences in the effectiveness of taking iron tablets against changes in hemoglobin levels in second trimester pregnant women at Sindang Barang Bogor Community Health Center.

Methods: Quasi experimental research with Pretest-Posttest Control Group Design. The sample is divided into two groups, namely the intervention group and the control group. The intervention group was given iron tablets simultaneously by drinking orange juice for 30 days.

Result: The provision of iron tablets simultaneously drinking with lemon juice water is more effective than the provision of iron tablets simultaneously drinking with lemon juice water is more effective than the provision of iron tablets simultaneously drink with water in pregnant women second trimester.

Conclusion: By giving vitamin $\mathrm{C}$ in the form of tablets or orange juice or foods or tablets of vitamin $\mathrm{C}$ can increase the absorption og iron pregnant women.
\end{abstract}

Keywords: Iron tablets, Hemoglobin, Pregnancy 


\section{BACKGROUND}

The pregnancy period starts from conception until the birth of the fetus. The duration of normal pregnancy is 280 days (40 weeks or 9 months 7 days) calculated from the first day of the last menstruation (Manuaba, 2007). Pregnancy is divided into 3 quarters, i.e. the first quarter starts from conception to 3 months, the second quarter from the fourth month to 6 months, the third quarter from the seventh to 9 months (Pearce, 2016). In addition, pregnant women experience changes in blood circulation, causing anemia in pregnancy. In the form of $\mathrm{Fe} 2+$ in hemoglobin gives the blood red color. Under normal circumstances $100 \mathrm{ml}$ of blood contains 15 grams of hemoglobin capable of carrying 0.03 grams of oxygen (Damayanti, 2015).

Iron is a substance that is difficult to be absorbed by the body so vitamin $\mathrm{C}$ is needed so that iron can be absorbed optimally. Iron absorption is greatly influenced by the availability of vitamin $C$ in the mother's body. In one orange contains 30 to $50 \mathrm{mg}$ of vitamin C (Setyaningsih, 2015). Vitamin C is a source of reducing equivalent in the whole body. Some enzyme reactions have been specifically shown to require vitamin $\mathrm{C}$, such as a hydrocilation process that uses oxygen molecules and often has an iron or copper cofactor. In this reaction vitamin $\mathrm{C}$ has two roles as a source of electrons to reduce oxygen and as a protective agent to maintain the iron reduction status (Febianty, 2013).

Giving iron preparations $60 \mathrm{mg} /$ day can increase Hb levels by $1 \mathrm{gr} \%$ / month. Oral iron therapy should not be stopped after hemoglobin reaches normal values, but it must be continued for another 2-3 months after post partum to improve iron reserves (Fitri, 2016).

\section{OBJECTIVE}

This study aims to examine the differences in the effectiveness of taking iron tablets against changes in hemoglobin levels in second trimester pregnant women at Sindang Barang Bogor Community Health Center.

\section{METHODS}

Quasi experimental research with Pretest-Posttest Control Group Design. Place of research for Sindang Barang Bogor Community Health Center. The study population was second trimester pregnant women selected and willing to be the subject of research. The selection of Puskesmas was conducted purposively with consideration of 1) having a prevalence of anemia of pregnant women from 2016 to April 2017 as many as 154 pregnant women, 2) second trimester pregnant women. Criteria for inclusion of subjects included healthy pregnant women who were willing to become respondents by taking supplements given during the study. Exclusion criteria are pregnant women who are not willing to be respondents or resign as samples for some reason, pregnant women due to illness or relocation. Subjects were grouped into two treatments, namely group one: 1) the intervention group was giving iron tablets together with drinking lemon juice as many as 16 respondents, 2) the control group was administering iron tablets together with drinking water as many as 16 respondents. Each group was tested for an initial hemoglobin level (pretest). Then the intervention group was given iron tablets together with drinking lemon juice for 30 days, for the control group was given iron tablets together with drinking water for 30 days. After 30 days, another hemoglobin level check is performed to find out whether or not there is a difference in the effectiveness of how to take iron tablets for changes in hemoglobin levels in pregnant women.

The analysis carried out in the form of univariate analysis to find a descriptive picture of the data collected between the mean, median, standard deviation, and Hb levels. While the 


\section{Journal Of Nursing Practice}

http://thejnp.org

ISSN: 2614-3488 (print); 2614-3496 (online)

Vol.3 No.2. April 2020. Page.188-192

bivariate analysis was conducted to see differences in the initial $\mathrm{Hb}$ levels (pretest), final $\mathrm{Hb}$ levels (posttest) both the intervention group or the control group.

To find out the difference in $\mathrm{Hb}$ levels before and after treatment, the different test used was the Independent Samples t test. Test to analyze data on differences in the average value of $\mathrm{Hb}$ levels before and after iron tablets were given to each group using the Paired $\mathrm{T}$-Test. The difference between the intervention group and the control group is significant if $\rho<0.05$.

The participants were assured that their engagement was voluntary, and that anonymity, privacy, and confidentiality of the data were guaranteed. Furthermore, they were informed about the purpose and the method of the study before signing a written informed consent

\section{RESULTS}

The results showed the mean 22 pregnant women $(68.75 \%)$ were second trimester pregnant women with multigravida pregnancy. Based on statistical test Paired T-test with a 95\% confidence level to see the difference in average levels of Hemoglobin in pregnant women in the iron tablet group together with drinking squeezed orange juice before being given an intervention and after being given an intervention the results showed a significant increase in hemoglobin levels that is before being given the treatment of hemoglobin levels in pregnant women an average of $10.63 \mathrm{gr} \%$ increased to $11.32 \mathrm{gr} \%$ with a significance $\rho$ $=0.008$.

There is an increase in hemoglobin levels of second trimester pregnant women in Sindang Barang health center from 7 pregnant women (43.7\%) increased to 10 pregnant women $(62.5 \%)$ with normal hemoglobin levels and pregnant women who experiencing mild anemia in 8 pregnant women $(50 \%)$ decreased to 6 pregnant women $(37.5 \%)$. This is influenced because in one orange contains 30 to $50 \mathrm{mg}$ of vitamin C. Vitamin C is a source of reducing equivalent in the whole body. In this reaction vitamin $\mathrm{C}$ has 2 (two) roles, namely as a source of electrons to reduce oxygen and as a protective agent to maintain the iron reduction status. Vitamin $\mathrm{C}$ is needed to increase the absorption of iron in the body. Increasing vitamin $\mathrm{C}$ consumption by 25 to $50 \mathrm{mg}$ can increase iron absorption

\section{DISCUSSION}

Based on the Paired T-Test with a confidence level of $95 \%$ to see the difference in the effectiveness of iron tablets for changes in hemoglobin levels in second trimester pregnant women at the Sindang Barang Health Center in 16 respondents with iron tablets simultaneously drinking with lemon juice for 30 days with giving iron tablets at the same time drinking with water for 30 days obtained results $\rho=0.035$, which means giving iron tablets simultaneously drinking with squeezed orange juice is more effective than giving iron tablets simultaneously drinking with water in second trimester pregnant women at Puskesmas Sindang Item in 2017.

Fe tablets (iron) are iron needed for blood formation, in the form of tablets containing 60 $\mathrm{mg}$ of iron and 500 micrograms of red folic acid to overcome and prevent anemia or anemia (Almatsier, 2010).

One of the effects of iron deficiency is anemia. Anemia in pregnancy is a condition of pregnant women with hemoglobin levels below 11 gr\% (Giyanti, 2016; Irianti, 2019). The need for iron in second trimester pregnant women begins by giving one tablet a day as soon as possible after the nausea disappears, and at least $500 \mathrm{mg}$ of folic acid each 90 tablets. Each tablet contains $200 \mathrm{mg}$ of ferric sulfate excikatus (equivalent to $60 \mathrm{mg}$ 


\section{Journal Of Nursing Practice}

http://thejnp.org

ISSN: 2614-3488 (print); 2614-3496 (online)

Vol.3 No.2. April 2020. Page.188-192

element $\mathrm{Fe}$ ) and $0.25 \mathrm{mg}$ of folic acid. Examples of Fe preparations include: baralat, biosanbe, vitonal, hemaviton, sangobion and hufabion which can be purchased freely (Istikharoh, 2005). Organic acids such as vitamin C greatly help the absorption of non-hem iron by changing the shape of ferries to ferrous. Ferrous forms are easily absorbed. Vitamin $\mathrm{C}$ besides changing the ascorbate iron group which remains soluble at higher $\mathrm{pH}$ in the duodenum (Lestari, 2011). Therefore, it is highly recommended to eat vitamin C foods such as guava, oranges and pineapple at every meal (Kristyan, 2011)

With the provision of vitamin $\mathrm{C}$ in the form of tablets or orange juice can increase the absorption of iron in pregnant women. In one orange contains 30 to $50 \mathrm{mg}$ of vitamin $\mathrm{C}$. Vitamin $\mathrm{C}$ is needed to increase the absorption of iron in the body. Increased consumption of vitamin $\mathrm{C}$ as much as 25 to $50 \mathrm{mg}$ can increase iron absorption (Litasari, 2014).

A significant difference between the initial hemoglobin level (pretest) and the final hemoglobin level (posttest) in the intervention group showed that administration of iron tablets together with drinking squeezed orange juice could help increase hemoglobin levels in second trimester pregnant women (Nurhayati, 2015). Vitamin C has a very important role in the absorption of iron, especially from non-hem iron which is found in many plant foods, so that it can help increase hemoglobin levels in pregnant women (Ristica, 2013).

\section{CONCLUSION}

The difference in average hemoglobin levels in the two treatment groups shows that iron absorption will increase if there is acid in the stomach. This acidic state can be improved by consuming tablets with blood, meat or fish which can stimulate stomach acid production. It can also be done by giving iron tablets together with vitamin $\mathrm{C}$ (squeezed orange juice) so that it gives an acidic atmosphere in the stomach.

Vitamin $\mathrm{C}$ is a source of reducing equivalent in the whole body. Some enzyme reactions have been specifically shown to require vitamin $\mathrm{C}$ such as a hydrolysis process that uses oxygen molecules and often has an iron or copper cofactor. In this reaction vitamin $\mathrm{C}$ has 2 (two) roles, namely as an electron source to reduce oxygen and as a protective agent to maintain the iron reduction status. In iron metabolism, it mainly accelerates the absorption of intestinal iron and its transfer into the blood. Vitamin $\mathrm{C}$ can also be involved in mobilizing iron deposits, especially hemosiderin in the spleen. Vitamin $\mathrm{C}$ is needed to increase the absorption of iron in the body. Increasing consumption of vitamin $\mathrm{C}$ as much as 25 to $50 \mathrm{mg}$ can increase iron absorption.

The need for iron during pregnancy increases, this increase is intended to supply the needs of the fetus to grow (fetal growth requires a lot of iron). Placental growth and an increase in maternal blood volume are around $1000 \mathrm{mg}$ during pregnancy. The need for iron during trimester 1 is relatively small at $0.8 \mathrm{mg}$ daily, which then rises sharply during trimester 2 and 3 at $6.3 \mathrm{mg}$ daily.

\section{CONFLICT OF INTEREST}

The authors declare no conflicts of interest

\section{ACKNOWLEDGEMENT}

The authors wish to appreciate all participant, whose contributions enabled the production of this article 


\section{Journal Of Nursing Practice}

http://thejnp.org

ISSN: 2614-3488 (print); 2614-3496 (online)

Vol.3 No.2. April 2020. Page.188-192

\section{REFERENCES}

Almatsier, S., Soetardjo, S., \& Soekatri, M. (2017). Gizi seimbang dalam daur kehidupan. Jakarta : PT Gramedia Pustaka Utama.

Argana, G., Kusharisupeni., \& Utari. D. M. (2004). Vitamin C sebagai faktor dominan untuk kadar hemoglobin pada wanita usia 20-35 tahun. Jurnal Kedokteran Trisakti, 23(1), 6-14.

Damayanti, I. P., Liva Maita, S. S. T., Kes, M., Ani Triana, S. S. T., Kes, M., Rita Afni, S. S. T., \& Kes, M. (2015). Buku Ajar: Asuhan Kebidanan Komprehensif Pada Ibu Bersalin dan Bayi Baru Lahir. Yogyakarta: Deepublish.

Febianty, N., Sugiarto, C., \& Sadeli, L. (2013). Perbandingan Pemeriksaan Kadar Hemoglobin Dengan Menggunakan Metode Sahli dan Autoanalyzer Pada Orang Normal. Thesis. Universitas Kristen Maranatha.

Fitri, Y. P., Briawan, D., Tanziha, I., \& Madanijah, S. (2016). Tingkat Kecukupan dan Bioavailabilitas Asupan Zat Besi pada Ibu Hamil di Kota Tangerang. Media Kesehatan Masyarakat Indonesia, 12(3), 185-191.

Giyanti, F., \& Wahtini, S. (2016). Pengaruh Pemberian Tablet Fe Terhadap Kenaikan Kadar Hemoglobin Remaja Putri Dengan Anemia Di Smk Negeri I Ponjong Kabupaten Gunungkidul Tahun. Thesis. Universitas' Aisyiyah Yogyakarta.

Irianti, B. (2019). Hubungan Volume Darah pada Saat Menstruasi dengan Kejadian Anemia pada Mahasiswa Akademi Kebidanan Internasional Pekanbaru Tahun 2014. Ensiklopedia of Journal, 1(2). 257-261.

Istikharoh, I. (2005). Pengaruh Suplemen Tablet Besi Dan Suplemen Vitamin C Terhadap Kadar Haemoglobin (Hb) Pada Remaja Putri. Thesis. Diponegoro University.

Kristyan, N. (2011). Perbedaan Kadar Hemoglobin Sebelum Dan Setelah Pemberian Tablet Besi $(\mathrm{Fe}$ ) pada Santri Putri di Pondok Pesantren Al-Hidayah Kabupaten Grobogan. Thesis. Universitas Negeri Semarang.

Lestari, D. (2011). Uji Toleransi Lambung Terhadap Fero Sulfat Yang Diberikan dalam Cangkang Kapsul Alginat pada Penderita Anemia Defisiensi Besi. Thesis. Universitas Sumatera Utara.

Litasari, D., \& Sartono, A. (2014). Kepatuhan minum tablet zat besi dengan peningkatan kadar hb ibu hamil di Puskesmas Purwoyoso Semarang. Jurnal Gizi, 3(2). 25-33.

Manuba, I. B. G. (2007). Ilmu Kebidanan, penyakit kandungan dan keluarga berencana untuk pendidikan bidan. Jakarta. EGC.

Nurhayati., Halimatusakdiah., \& Asniah. (2015). Pengaruh Asupan Tablet Zat Besi (Fe) Terhadap Kadar Haemoglobin (Hb) Pada Ibu Hamil Di Puskesmas Kopelma Darussalam Tahun 2014. Idea Nursing Journal, 6(1), 76-82.

Pearce, E. C. (2016). Anatomi dan fisiologi untuk paramedis. Jakarta: PT Gramedia Pustaka Utama.

Ristica, O. D. (2013). Faktor Risiko Kejadian Anemia pada Ibu Hamil. Jurnal Kesehatan Komunitas, 2(2), 78-82. https://doi.org/10.25311/jkk.Vol2.Iss2.49

Setyaningsih, W., Ani, L. S., Utami, N. W. A., Setyaningsih, W., Ani, L. S., \& Utami, N. W. A. (2015). Konsumsi besi folat, tingkat kecukupan energi dan zat besi berhubungan dengan kejadian anemia ibu hamil di Kabupaten Jember. Journal of Public Health and Preventive Medicine. 3(1).

https://doi.org/10.15562/phpma.v3i1.79 